\title{
Transformation of Education Processes and Preparation of Competencies for the Digital Economy
}

\author{
Olga V. Kosenchuk ${ }^{1,}$, Mikhail N. Kulapov ${ }^{2}$, Yuliya A. Diner ${ }^{1}$, Alla V. Zinich ${ }^{1}$, Yulia N. \\ Revyakina ${ }^{1}$ and Alexey O. Adelfinskiy ${ }^{3}$
}

${ }^{1}$ Omsk State Agrarian University, 644008, 1, Institutskaya sq., Omsk, Russia; ${ }^{2}$ Plekhanov Russian University of Economics, 117997, Moscow, Stremyannyi Alley, 36, Moscow, Russia and ${ }^{3}$ Moscow State Pedagogical University, 119991, st. Malaya Pirogovskaya, building 1, building 1, Moscow, Russia

\begin{abstract}
In this article, the problem of training specialists with digital competencies for the agricultural sector, as the main industry, necessary for the food security of the state. The analysis of the views of researchers on the issues of teaching youth in the context of global digitalization is presented. The analysis and generalization of information about modern technologies in the system of training personnel for the agro-industrial complex, taking into account the experience of the Omsk State Agrarian University, with the support of modern information and communication technologies. The idea is substantiated that digitalization of production and management processes in the agro-industrial complex is impossible without hard and soft skills with new competencies. The article summarizes new material based on the results of a survey of rural youth in Russia and Kazakhstan on the problem of professional self-determination. The characteristic features of modern students and their self-positioning in the conditions of a changing professional environment are highlighted and described. Special attention in the work of the authors is focused on the need to form an educational trajectory, which is based on the symbiosis of classical agricultural education, practice-oriented learning, project activities, concepts - technologies, e-learning and other digital educational resources. The conclusion reveals the authors' opinion on the forecast trends on the issue under study.
\end{abstract}

Keywords: Youth, Professional self-determination, Training, Omsk State Agrarian University, Survey, Digital competencies.

\section{INTRODUCTION}

The global political and socio-economic challenges faced by Russia revealed an urgent need for a new type of agricultural economy, which is based on the use of modern information technologies (Plotnikov, 2019).

Agrarian policy is an integral part of the state socioeconomic strategy aimed at sustainable development of agriculture and rural areas. So, according to the Strategy for the Development of Agrarian Education of the Russian Federation until 2030 (Strategies for the development), the agricultural industry needs specialists with skills and professional competencies that meet the requirements of modern technological and science-intensive production (in particular, in the field of genetic engineering, robotization of production, precision farming).

The sphere of education, together with other sectors such as health care and agriculture, is undergoing significant transformation due to the active introduction of information technologies into production. Currently, there is a significant shortage of personnel in the agro-industrial complex, especially with digital

*Address correspondence to this author at the Omsk State Agrarian University, 644008, 1, Institutskaya sq., Omsk, Russia; E-mail: 9250361917@mail.ru competencies. In this regard, the training of specialists requires new approaches in education, taking into account modern trends and employers' requirements.

The agro-industrial complex is one of the largest intersectoral complexes in the structure of the national economy. It includes diverse areas of the economy, including agriculture and certain industries associated with agricultural production. And traditionally it occupies a special place in the Russian economy. The problems of its functioning are associated not only with natural and biological risks, but also with the complexity of managing living systems using digital technologies.

The purpose of the article is to analyze trends in higher education and the use of new approaches in training students of agricultural universities for the formation of competencies necessary in the context of digitalization of the agro-industrial complex, using the example of the experience of the Omsk State Agrarian University. P.A. Stolypin.

\section{LITERATURE REVIEW}

A number of scientists have studied the formation of human and intellectual capital as the main resource for the development of the digital economy, which determines its effectiveness. They noted that the primary task of the education system will remain the 
training of personnel with the necessary competencies, and the most productive workforce in the digital economy will be the symbiosis of a human and a friendly intelligent robot (Novoselova, 2020; Loginova, 2019; Usamov, 2019). The federal educational standards of the new generation should reflect the key competencies associated with the development of a digital society. New personnel need to be fluent in information technology. And this can be achieved through the digital transformation of Russian education while strengthening the consolidation of students and university teachers, employers and government bodies (Taratynova, 2020; Kirikov, 2020; Likhosherstova, 2019; Derenko, 2020).

(Tashbaev, 2019) in Kyrgyzstan, the active use of information and communication technologies gives positive results in training. At the same time, A.V. Gornostaeva, O.V. Kolosova. and Chernyshov S.A. (Gornostaeva, 2020; Chernyshov, 2019) explain the impact of the ongoing transformation of the labor market on the higher education system and the importance of acquiring future specialists with digital competencies. Knowledge of the psychology of modern youth is of great importance in building a new format of education. So, Sibgattulina I.F., Merzon E.E., Kozhevina O.V. (Sibgatullina, 2019; Kozhevina, 2019) in their studies studied the issues of talent management in the context of the development of the digital economy, Shvachko E.V. and Duranov M.E. (Shvachko, 2019) - issues of passionate impulse and problems of socio-cultural education of youth.

\section{METHODS}

The work used analytical methods and methods of sociological research. Analytical methods are aimed at studying current trends in the educational space, taking into account the trends of global digitalization of production and socio-economic processes. When studying this problem, one of the methods was a sociological survey on the topic: "Professional selfdetermination of modern youth", conducted in 2020 by employees of the Omsk State Agrarian University.

The information and empirical base is the information obtained by the authors as a result of their own research. To compare the processes of professional self-determination, the sample included students from agricultural universities in Russia and the Republic of Kazakhstan. The study involved students of 1-4 courses aged 18-30 years. Its implementation involved quota-nested sampling when processing online questionnaires. This article presents an analysis of a fragment of expert opinions. The respondents defined the level of their computer literacy: from novice user to advanced (at the level of self-diagnosis). The skills of working with digital information were assessed: starting from its search, ending with the creation and ensuring its safety (where 1 point is the lack of this skill, 5 points is its mastery). Also, young people were asked to determine the priority areas of using digital devices from the proposed list: I use them in the educational process or for advanced training, for communication, online shopping, for entertainment. In addition to defining digital competencies, students identified the most important success factors in the labor market, choosing between focusing within the profession, or prioritizing interdisciplinary interactions.

\section{RESULT}

The study showed that only $9 \%$ of Russian respondents consider themselves advanced users. Representatives of Kazakhstan are more confident in their abilities. This level of computer literacy was stated by about $16 \%$ of the respondents. The majority of young people consider themselves middle-level users (42 and $47 \%$ are residents of Kazakhstan and Russia, respectively). Slightly more than a third of respondents consider themselves to be confident users (Figure 1).

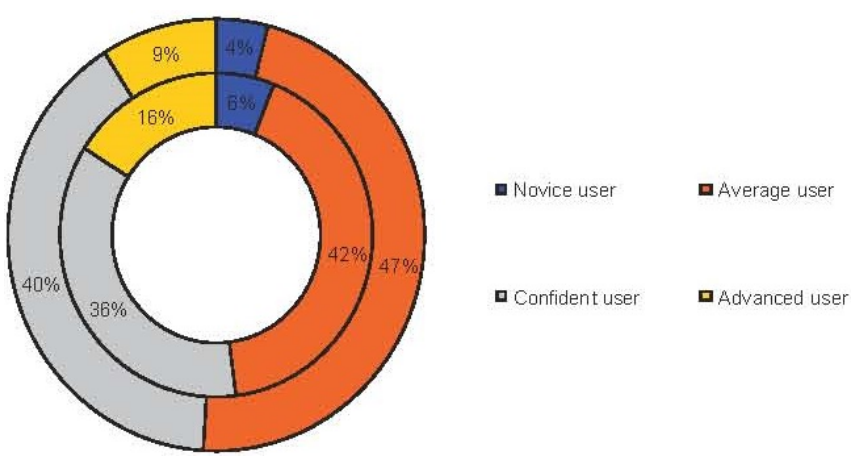

Figure 1: Distribution of the share of respondents by the level of computer literacy (at the level of self-determination), \% (Source: Author)

Next, we asked to rate on a 5-point scale the level of proficiency in the following skills: creation, search, analysis, exchange of digital information and ensuring its security (Figure 2). The respondents from Russia rated the skills of searching and exchanging digital information the highest, with an average of 4.1 points, difficulties are caused by operations related to the creation of digital information and ensuring its security. At the same time, respondents from Kazakhstan rated 


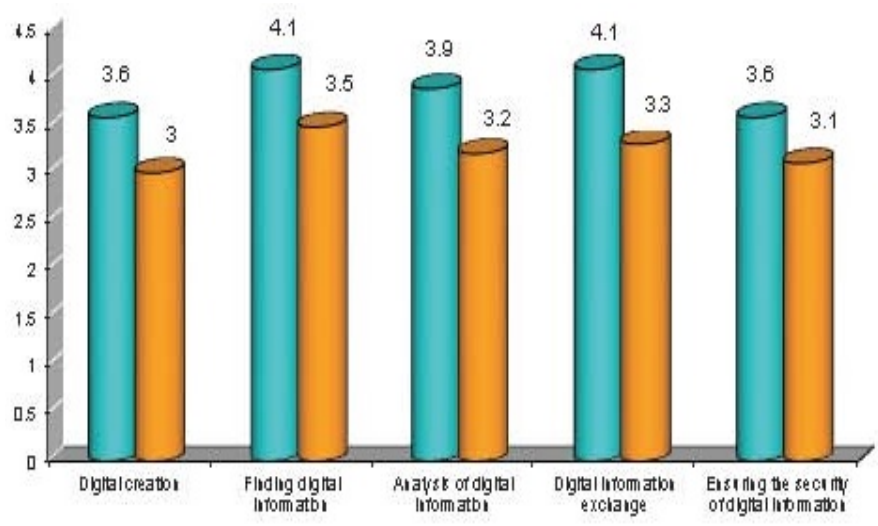

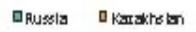

Figure 2: Respondents' assessment of skills in working with digital information, points (Source: Author).

the level of proficiency in all skills on average by 3 points.

According to the survey results, all respondents have in use at least one modern digital device (smartphone, computer, laptop, tablet, etc.). Regardless of the country of residence, the answers were distributed in a similar way (Figure 3). Thus, the majority of respondents use gadgets mainly for communication in social networks, instant messengers and other applications (85\% in Russia and $76 \%$ in Kazakhstan). In second place in terms of the frequency of access to devices is the learning process, which is primarily associated with the age of the respondents. Thus, about $70 \%$ of Kazakhstani and $80 \%$ of Russian respondents chose this answer option.

In the new conditions of the digital economy, the demand for interdisciplinary specialists with competencies in two or more areas is increasing. The division into humanitarian and technical profiles is gradually being erased. Modern students are gradually realizing the need for an interdisciplinary approach to education. Thus, $56 \%$ of the Russian and $35 \%$ of Kazakh students surveyed have already realized that being successful in the labor market requires the possession of competencies at the intersection of professions (Figure 4). About a third of the respondents in both countries adhere to a conservative view aimed at professionalism in the chosen field. Those who believe that success in the labor market does not depend on the level of competencies accounts for $12 \%$ of respondents in Russia and $27 \%$ in Kazakhstan.

In general, the survey showed that the majority of young people are ready to get involved in the process of digitalization of education and form their digital professional competencies. And the insignificant

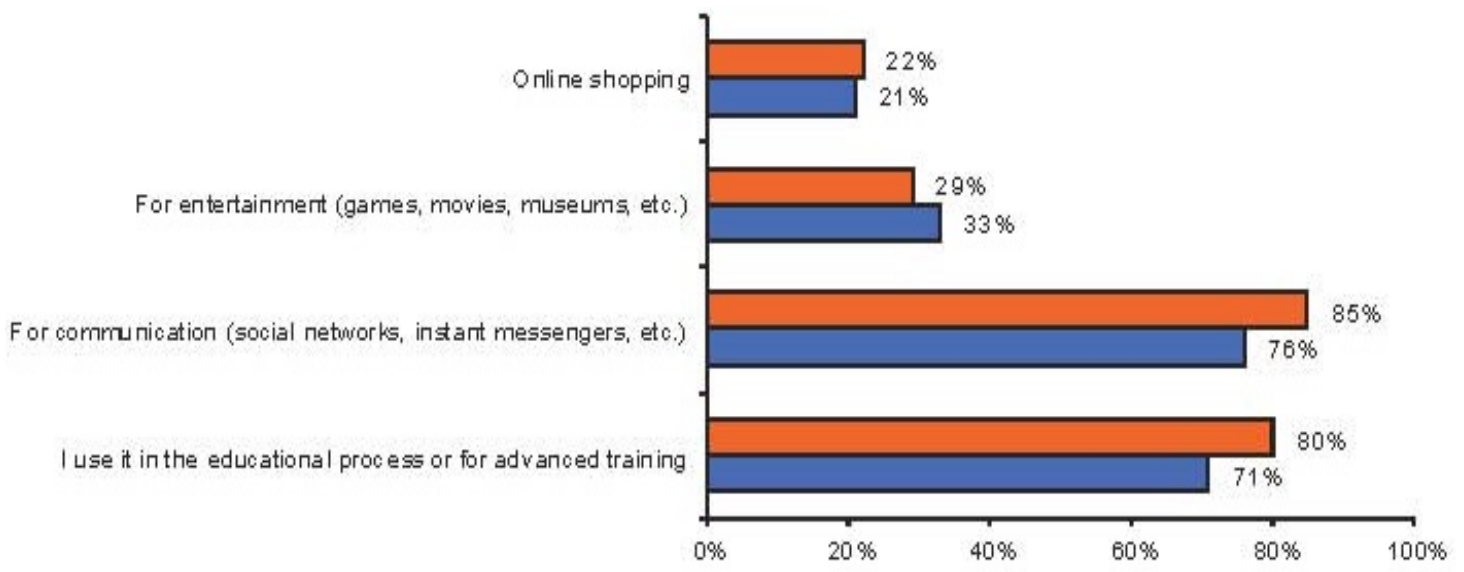

Figure 3: Priority areas of the respondents' use of digital devices, \% of respondents (Source: Author). 

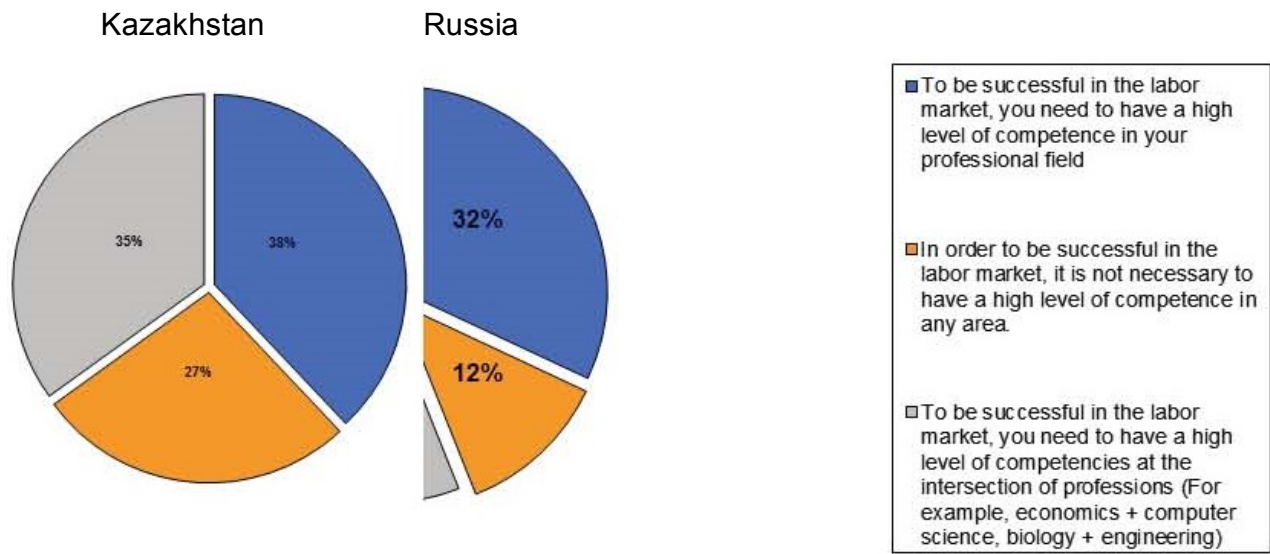

Figure 4: Identification of the most important success factors in the labor market, \% (Source: Author).

difference in the answers received by respondents from different countries indicates the influence of the globalization process on the formation of the mindset and digital skills of the younger generation.

\section{DISCUSSION}

A number of researchers O. Kosenchuk, O. Shumakova, A. Zinich, S. Shelkovnikov, A. Poltarykhin (Kosenchuk, 2019) point to an increase in demand for universal specialists in the agro-industrial complex who have the skills to integrate intelligent solutions and are at the same time versed in agriculture. Bondarenko T.A., Zeiliger A.M., N.V. Zastrogin and others (Boronenko, 2020; Zeiliger, 2020; Zastrogin, 2020) note the obvious inevitability of the transition of agrarian education and methods of training students to new educational programs and standards, modern information platforms, digital technologies, information resources and online courses that allow improving the professional level of knowledge, skills nii and skills. E.A. Minina (Minina, 2019) emphasizes that when updating the subjects of academic disciplines and organizing the educational process in a distance format, it is necessary to take into account not only global trends, but also regional characteristics. In addition, as the successful world practice of the EAEU countries and Europe shows (Bogdan, 2019; llinykh, 2019; Zakirova, 2019), it is necessary to develop a system of continuous education in the context of Industry 4.0, and it is necessary to introduce new educational technologies into the educational process. According to Tashbaev A.M. Omsk State Agrarian University. P.A. Stolypin (Omsk State Agrarian University) - one of the oldest higher educational institutions in the Russian Federation, which trains personnel for agriculture. Today, the university solves the most important task in the field of providing highly qualified specialists in the agro-industrial sector of the Omsk region, which is the largest industrial-agrarian region of Russia. The combination of many years of traditions in research and educational activities with modern methods of training specialists in the context of globalization and digitalization of processes is a distinctive feature of the policy of Omsk State Agrarian University, which allows it to enter the TOP of the best universities in Russia and be the only representative of Siberia in the list of the best universities of the Ministry of Agriculture farms.

The research team realizes that in order to successfully implement the policy chosen by the university in the context of global digitalization, it is necessary not only to encourage the development of digital professional competencies, but also to focus on their basic level among students. Today digital literacy is becoming not just a competence, it is a basic life skill of today's youth, most of whose communication processes take place online.

The obvious task of educational institutions in such conditions is the development of digital competencies in students, focusing on the professional component, as well as their involvement in interdisciplinary projects implemented using digital educational resources.

In the draft Program for the development of the agro-industrial complex of the Omsk region for 2020 2025 , special attention is paid to the training of specialists for the regional agro-industrial complex. Omsk State Agrarian University assumes responsibility for the formation of an educational agenda in the field of training personnel for the countryside, satisfying the needs of the agricultural sector at the present stage of development. 
The preparation of competencies for the modern agro-industrial complex today is impossible without the use of practice-oriented learning, the concept of smart technologies, e-learning, digital educational resources, student participation in project activities. The result of practice-oriented training should be a specialist who is able to effectively apply his existing competencies in his work. Students of the agrarian university implement this approach during their educational, industrial, prediploma and research practice.

At the Omsk State Agrarian University named after P.A. Stolypin, for many years, the concept of integration into the educational space of the leading regional manufacturers of agricultural products, the socalled dual education, has been successfully implemented, which allows the formation of the necessary competencies for students in the real conditions of the activity of an enterprise in the agricultural sector and motivates them to professional self-improvement. For an enterprise, dual education is an opportunity to prepare personnel for themselves "on order", ensuring their maximum compliance with all their requirements, saving on the search and selection of personnel, their retraining and adaptation to the realities of production.

The implementation of a practice-oriented approach at Omsk State Agrarian University is possible due to the developed university infrastructure and competent policy of the university administration, which made it possible in difficult socio-economic conditions to preserve experimental fields, farms, and modernize the university veterinary clinic.

An important form of enhancing the process of assimilating knowledge in the preparation of future specialists is the performance of various types of design work. The generalized practice of preparing design work shows the usefulness of observing the following logical sequence: determination of the chosen topic (problem) for presentation in the design work and the formation of the corresponding idea; search for sources of information; system thematization of materials and development of a plan for writing a project; writing a project. When comprehending the problem and forming the idea of writing a project, it is important to clearly define: what problem is being solved; what kind of project work is being prepared; the theoretical substantiation of the problem is emphasized or practice is generalized. Thus, a project-oriented approach in the educational process remains extremely important.
The successful experience of implementing project activities in the educational process by students and employees of Omsk State Agrarian University was obtained during the implementation of the Networked Educational Intensive of the University of the National Technology Initiative "20.35". As part of the event, trainings were held with the involvement of leading industry experts and business trainers, the participants of the intensive got access to laboratory sites and electronic resources for the implementation of the practical part of the projects.

The implementation of the event made it possible not only to obtain and consolidate competencies in the field of project activities, but also to conclude partnership agreements on project work between the largest universities in the region, to start shaping an agenda for a single project-oriented educational space in Omsk with the involvement of leading scientists, specialists, expert community.

It should be noted that Russia is developing and subsequently scaling up a whole range of complex digital solutions for agricultural enterprises: smart farm, smart field, smart herd, smart greenhouse, smart processing, smart "Warehouse and" smart "agricultural office. Smart technologies work, first of all, with the information environment, their main task is data collection and analysis, monitoring of various processes. In the agro-industrial complex, the range of application of such solutions is quite wide: with the help of SMART technologies, they monitor the operation of large-sized equipment, control soil cultivation, planting and harvesting, fertilization, regulate the productivity of farm animals, etc.

For example, the integration of the educational process with production to train the competencies of zooengineers and veterinarians using modern software systems and digital solutions in animal husbandry (SELEX is a program for collecting primary zootechnical data, DataFlow is a comprehensive and intuitive dairy herd management system, analytical programs for herd management "Simple solutions" and "UNIFORM-AGRI", programs for optimizing feed rations "Korm Optima Expert" and "CORAL", and others) on the example of real business processes of enterprises in real time allows students to provide access to means of objective control over the physiological state of farm animals, planning and production management tools with Big Dat elements, a macro-demand forecasting platform, close integration of digital agriculture processes with platforms 
developed in the process of implementing the digital economy.

Gaining practical experience based on information SMART - technologies within the framework of the transformation of agro-education is becoming a priority in the preparation of qualified personnel for the regional agro-industrial complex.

\section{CONCLUSION}

The training of qualified personnel for the new economy should be carried out inseparably with the digital transformation of domestic education. These processes are changing both the labor market and the entire system of vocational training and selfdetermination of young people. Today, education goes beyond classrooms, uniting universities, the international business and scientific community on one platform, involving students in project activities and providing young people with almost unlimited opportunities in the formation of new competencies. As the study showed, today's youth in general is ready to accept new trends, they already have the necessary basic skills to work with digital information. The task of a modern higher school is not only to ensure the acquisition of professional competencies in a certain area, but also to create communities of a new level, allowing students to work in interdisciplinary teams that can meet the challenges of the new digital economy.

\section{LIMITATIONS OF THE STUDY}

When studying the issues of professional selfdetermination of young people, we used a quotanested sample of questionnaires of students of higher educational institutions ( $\mathrm{N}=385)$, which provides representativeness with a confidence level of $95 \%$. A larger sample coverage, for example, a survey of college students, or young people who do not study in vocational educational institutions, would give a more complete picture of trends in the development of the process of professional self-determination of young people in the context of digitalization.

\section{ACKNOWLEDGMENT}

The reported study was funded by RFBR, project number 19-29-07366.

\section{REFERENCES}

Plotnikov, A.V. (2019) The role of the digital economy for the agroindustrial complex: Moscow Economic Journal, 7, https://cyberleninka.ru/article/n/rol-tsifrovoi-ekonomiki-dlyaagropromyshlennogo-kompleksa
Strategies for the development of agricultural education in the Russian Federation until 2030. URL: http: //www.bsaa.edu.ru/sveden/files/Strategiya_AO.pdf (date accessed: 16.08.2020).

Novoselova, A.E. (2020) Additional vocational education in the context of the digital transformation of education: Predicting the professional future of youth in the digital economy. Materials of the All-Russian scientific-practical conference. Edited by E.F. Zeer, V.S. Tretyakova, Russia

Loginova, N.A. (2019) Transformation of the system for assessing the competencies of students in higher education institutions in the digital economy: Management of innovation and investment processes and changes in the digital economy. Collection of scientific papers on the results of the II international scientific and practical conference. Ed. G.A. Krayukhina, G.L. Bagieva, St. Petersburg, Russia. Pp. 188194.

Usamov, I.R. (2019) Digital transformation of education: problems and prospects: Bulletin of GGNTU. Humanities and socioeconomic sciences, T. 15, 3 (17). S. 80-86.

Taratynova, A.A. (2020) Requirements for education in the context of digital transformation of society: Current trends in the development of society: education, communication, psychology. Collection on the results of a scientific-practical conference with the participation of international experts, Rostov-on-Don, Russia, pp. 83-85

Kirikov, A.N. (2020) Topical issues of implementing digital transformation in education: The architecture of university education: building a unified space of knowledge. collection of works of the IV National Scientific and Methodological Conference with the participation of the international community, St. Petersburg, Russia, p. 69-74.

Likhosherstova, G.N. (2019) Digital transformation of Russian education in the context of the global economic space: essence, significance, problems: The experience of an educational organization in the field of digital skills formation. collection of materials of the All-Russian scientific and methodological conference with international participation, Russia.

Derenko, N.V. (2020) The role of digital transformation in higher education in enhancing the consolidation of students and teachers: Social consolidation and social reproduction of modern society: resources, problems and prospects. Materials of the VI All-Russian Scientific and Practical Conference, Russia

Kosenchuk, O.V. (2019) Development of agriculture in agricultural regions of Siberia: multifunctionality, environmental aspects [Electronic resource] Journal of environmental management and tourism, December 30, P. 991-1001. - URL: https: //journals.aserspublishing.eu/jemt/article/view/3997 (date accessed: 01/16/2020).

Boronenko, T.A., Fedotova, V.S. (2020) Prerequisites for the digital transformation of the Russian education system: Bulletin of Samara University. History, pedagogy, philology. T. 26, 2.S. 70-78

https://doi.org/10.18287/2542-0445-2020-26-2-70-78

Zeiliger, A.M., Ermolaeva, O.S. (2020) Transformation of the content and content of higher agricultural education for the development of digital agriculture in the Russian Federation: Reports of the TSHA, pp. 358-362.

Zastrogin, N.V., Latyshev, D.V., Skarzhinets, V.A., Kovazhenkov, M.A. (2020) Digital transformation of education: problems and prospects: Actual issues and practice. Collection of scientific papers based on the materials of the XVI International Scientific and Practical Conference, Anapa, Russia p.56-59.

Minina, E.A. (2019) Higher education in the context of digital transformation of education: organization of the educational process: Modern education: global trends and regional aspects. Collection of materials of the interuniversity scientific-practical conference, Russia. 
Bogdan, N.I. (2019) Problems of transformation of the higher education system of the EAEU countries in the digital economy: Greater Eurasia: Development, security, cooperation. Yearbook. Proceedings of the XVIII International Scientific Conference at the Public Scientific Forum "Russia: Key Problems and Solutions", Moscow, Russia, p. 880-882.

llinykh, G.S. (2019) On the issue of digital transformation of higher education (foreign experience): Actual problems of modern higher education: from general to specific. Collection of materials of the IV Regional Scientific and Methodological Seminar, Khabarovsk, Russia, p. 26-32

Zakirova, ER, Veselukhina, P.V. (2019) Vocational Education 4.0: Learning in a Digital Transformation - German Experience: Developing a Continuing Education System in Industry 4.0. Materials of the International Scientific and Practical Conference, Russia.

Tashbaev, A.M. (2019) Digital transformation and the state of application of information and communication technologies in education: Science, new technologies and innovations of Kyrgyzstan, 10, pp. 109-115.

Gornostaeva, A.V., Kolosova, O.V. (2020) Trends in the development of the labor market and education in Russia in the context of the digital transformation of the economy: Innovative technologies in educational activities. Materials of the AllRussian Scientific and Methodological Conference, Russia.

Chernyshov, S.A. (2019) Labor market transformation and challenges for the education system in the context of the development of the digital economy: EdCrunch Tomsk. Materials of the international conference on new educational technologies, Tomsk, Russia.
Sibgatullina, IF, Merzon, EE, Seibgll, A. (2019) Talent management in the context of digital transformation of education: Human Psychology in Education, Vol. 1, 2. P. 169-175. https://doi.org/10.33910/2686-9527-2019-1-2-169-175

Kozhevina, O.V. (2019) Management of digital transformation of education // Management in Russia and abroad, 6.P. 26-32.

Shvachko, E.V., Duranov, M.E. (2019) Issues of passionary impulse and problems of socio-cultural education of youth in the era of digital transformation of society // Pedagogical Science and Practice, 4 (26). S. 14-22.

\section{Authors}

Kosenchuk Olga Vitalievna, the candidate of agricultural Sciences, associate Professor, Dean of the faculty of animal science, commodity science and standardization

Kulapov Mikhail Nikolaevich, Doctor of Economics, Professor, Head of the Scientific School "Management Theory and Technologies"

Diner Yuliya Alexandrovna, the candidate of technical Sciences; Omsk State Agrarian University named after P.A. Stolypin

Zinich Alla Vladimirovna, Candidate of Sciences (PhD) in Economics, Omsk State Agrarian University named after P.A. Stolypin

Revyakina Yulia Nikolaevna, public relations Manager, Omsk State Agrarian University named after P.A. Stolypin

Adelfinskiy Alexey Olegovich, Doctor of Economics, Professor Professor of the Department of Economic Theory and Management.

DOI: https://doi.org/10.6000/1929-4409.2021.10.23

(C) 2021 Kosenchuk et al.; Licensee Lifescience Global.

This is an open access article licensed under the terms of the Creative Commons Attribution Non-Commercial License (http://creativecommons.org/licenses/by-nc/3.0/) which permits unrestricted, non-commercial use, distribution and reproduction in any medium, provided the work is properly cited. 